\title{
"Quaternity" Promotes the Construction of Moral Education Tutor for Engineering Students and the Actual Effect of Work
}

\author{
Fan Wenhui ${ }^{1}$, Chang Jingwen ${ }^{1}$, Bao Wenhua ${ }^{1}$, Ding Feng ${ }^{1}$, Han Yang ${ }^{1}$ *
}

${ }^{1}$ School of Mechanical Engineering, Beijing Institute of Technology, Beijing 100081, China

Keywords: engineering students; development needs of moral quality; moral tutorial system

\begin{abstract}
The education of moral quality in our country colleges is deficient, and the methods are relatively traditional and the effects are not satisfied. Taking Beijing Institute of Technology as an example, we built a full personal four-in-one moral tutorial system. That is to say, take the construction of the grass-roots party branches as the starting point, strengthen the effect of ideological and political education as well as the moral education; clear the responsibility of the class teacher, and strengthen their moral tutorial function; expand the technological innovation of teachers, teaching morals in both theory and practice; integrate the alumni services with the career development planning, and deepen the connotation of the moral tutorial system. After years of continuous exploration and practice in the School of Mechanical Engineering, Beijing Institute of Technology, many regulations and encouraging policies of performance have been formed to attract teachers taking part in the moral education. The quality of the graduates has been increased year after year.
\end{abstract}

\section{Introduction}

At present, the university moral education work in our country mainly focuses on infusing political and moral aspects of theory to the student thought, in the relative lack of team construction of ideological and political instructors. How to implement effective moral education for college students shows more important under now blundering utilitarian society. ${ }^{[1-3]}$ "moral education teacher" is the students' life coach, who plays a guiding role in setting up students' outlook on life, world outlook and the values. ${ }^{[4-5]}$ The main responsibility of "teachers of moral education" is to cultivate and guide the students' moral culture, the political quality, regulations, discipline, mental health, collective consciousness and social aspects of education. ${ }^{[6-7]}$ how to take these boring ideological education content into in the daily courses, social practice, recreational activity, innovation practice, career counseling and so on, from invisible to visible, it is the core of the research work of "moral education teacher".

\section{Research about the Construction of "Moral Education Teacher" of Engineering Students}

\subsection{In view of the students' quality development needs, concise mentor is the goal of moral education}

College students' ideological and political education work is the fundamental work in colleges and universities about education policy. The ideological and political education must not be divorced from teaching link. The first step, this research is to study the basic characteristics and training requirements of engineering college students, and outline the students' quality structure. The related interest's diagram of social demand and quality structure is shown in figure 1 . After concluding "engineering students' quality structure" model, we can analyze the model further, and then find breakthrough point of "teachers of moral education" in cultivating education.

Corresponding author: Han Yang (1991—), Male, master degree, teaching assistant, Beijing Institute of Technology, School of Mechanical Engineering, contact: 010-68914347, 13426123353, hanyang0316@126.com 


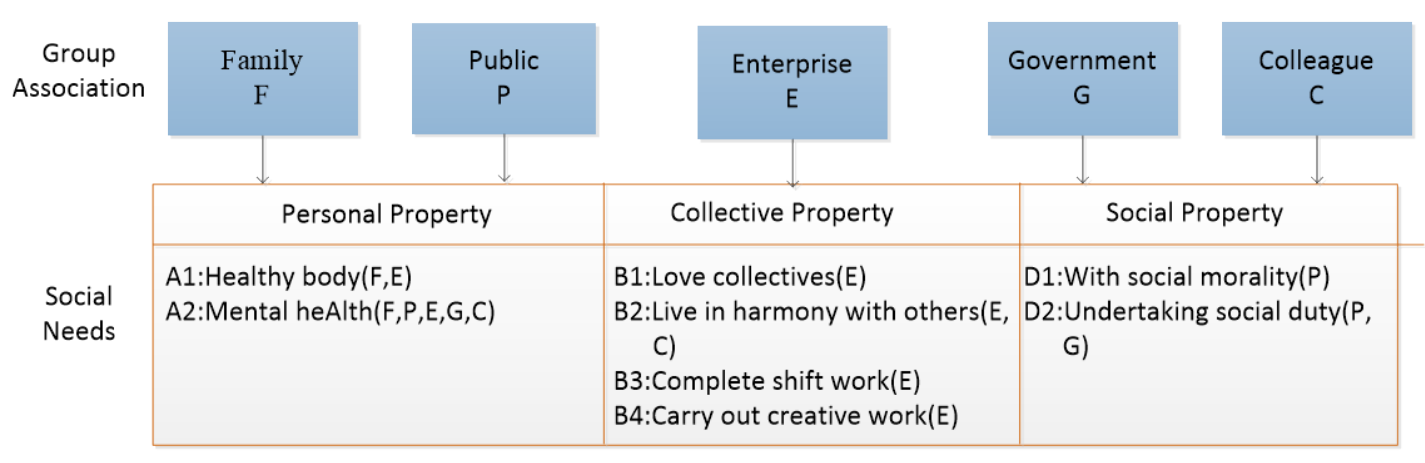

\begin{tabular}{|c|c|c|c|}
\hline & Morality & Knowledge & Physique \\
\hline $\begin{array}{l}\text { Quality } \\
\text { Structure }\end{array}$ & $\begin{array}{l}\text { X1:Moral cultivation(B1,B2,D1) } \\
\text { X2:Political quality(B1,D1,D2) } \\
\text { X3:Legal quality(B1,D1,D2) }\end{array}$ & $\begin{array}{l}\text { Y1:Academic performance(B3) } \\
\text { Y2:Professional skills(B3,B4) } \\
\text { Y3:Research ability(B4) } \\
\text { Y4:Study method(B3,B4) } \\
\text { Y5:Creativity(B4) } \\
\text { Y6:Social work(B2,B4,D2) } \\
\text { Y7:Practical activity(B3,B4,D2) } \\
\text { Y8:Cultural quality(B3,D2) } \\
\text { Y9:Artistic quality(B4,D2) } \\
\text { Y10:Foreign language skills(B2, } \\
\text { B4) }\end{array}$ & $\begin{array}{l}\text { Z1:Physical fitness(A1) } \\
\text { Z2:Psychological quality(A2, } \\
\text { B2,B4,D1) }\end{array}$ \\
\hline
\end{tabular}

Fig. 1 Stakeholders diagram of the social demand and quality structure

\subsection{On account of the integration of education teaching reform practice, set up a system of} "whole-staff-participation moral education teacher"

In the process of talent training, some colleges and universities divorced the students' ideological and political education, daily management from teaching links, As a result, many colleges and universities want to seek a kind of integrated education, teaching, scientific research and many other resources to promote the realization of the "whole-staff-participation education" and the improvement of teaching quality, that is the integration of education reform. The so-called integration of college education is a concrete research to the school, the scientific research, teaching, students' ideological and political education and management work, also known as "education teaching integration". ${ }^{[8-11]}$

The author build "four one" of "whole-staff-participation" mentor system of moral education, based on the integration of education reform in Beijing university of technology ,school of mechanical and vehicle, This job needs education administration and teaching department work together, start with the teacher in theory of basic-level party branch, undergraduate teacher in charge, scientific research and entrepreneurial guidance teacher, career planning supervisor, basic-level party branch construction, strengthen the moral education function of the teacher in charge and communities, expand scientific research and entrepreneurial guidance teacher number and complementary with career planning, promoting students' moral education teachers construction and improve the work efficiency.

\section{3. “Quaternity" Promotes the Construction of Moral Education Tutor for Engineering Students and the Actual Effect of Work}

\subsection{Enhance ideological and political effectiveness of moral education with the construction of grass-roots Party branch as the starting point}

As grass-roots party organizations in the college, student party branch is the basic unit of college student party members' education management, as well as the most effective carrier of education and management. Student party branch also guides and contact students effectively. The teachers' theory instruction and practice play an important role to the basic organization of the Party in students. ${ }^{[12]}$ 
In 2015, the school of mechanical and vehicle in Beijing Institute of Technology carried out the reformation of the graduate student's party branch organizations, breaking the system of divided by grade. The new basic student party branch is corresponding to the staff party branch, requiring

\subsection{Clarify the responsibility of the teacher, and strengthen the function of moral education}

The meeting about the class cadre will be convened at least once a month by the class teacher to understand a student cadre's work methods and the problems in the work, then give timely guidance. The class teacher should purposefully develop one or two assistant with good learning, ability strong and capable of driving the class.

The class teacher must take at least a conversation with each student every semester, and record the conversation. To understand the student's situation about life, study, family, etc. The class teacher must master the number of poor students, class learning situation of poor students and the situation of students having difficulty thinking. We should set special tracking files to students with family difficulties to do a good job of these students.

\subsection{Expand teachers who guides scientific research, and teach morality in theory and practice}

The methods that teachers anticipate in their children's extracurricular activities have a lot, it is worthy education workers to develop. Such as university teachers as class teachers organize class activities, university teachers as a social practice teachers, etc. Students in practice will inevitably encounter difficulties and bottlenecks, teachers solve the problem to help students further understand of knowledge theory, and train the students beginning ability, innovation ability and other comprehensive qualities. The way is built on the basis of the integration of education reform, through the construction of education administration and teaching integration, lead good first class teachers to participate in the activities of the students' extracurricular practice, to play well to promote quality education.

\subsection{Integrate of alumni services and career development planning, and deepen the connotation of moral education}

Conveying talents for the society is the most fundamental training goal of higher education, so the college students' career planning guidance is particularly important ${ }^{[13]}$. In Beijing university of technology school of mechanical and vehicle, we integrate alumni services, career guidance, career planning to establish the career development services centre, it service the alumni, at the same time ,the utilization of alumni resources service the career planning of college students, it played a good effect. Such as, school will carry out enterprise lecture hall on the eve of recruiting season every year, invite relevant enterprise alumni back to school for the students and employment situation of the industry; Especially under the background of entrepreneurship that national vigorously promote college students, enterprise lecture hall attract entrepreneurial alumni as a teacher to give experience and guidance for college students, explain how to combine their own professional knowledge and business.

\section{The Practice Effect}

\subsection{Accelerate the construction of moral education system with the system document as the starting point}

To improve the construction of tutor system of moral education, college teachers performance is linked to the moral education work, and consider the effect of a teacher's work when the year-end appraisal, we formed "the teacher in charge work documents and assessment indicators of the institute of mechanical and vehicle", "guidance teachers management method of innovation of students of science and technology", "the teachers involved in their student's work responsibilities and evaluation indicators", the documents clear the party branch theory of teacher's training time demands, the number of class activities the teacher in charge participate and motivation projects under the guidance of teachers, we offer certain performance bonus according to their workload.

\subsection{Verify the effectiveness of the work of moral instructors by the quality of employment}

After several years of practice, college graduates' comprehensive quality have been improved, Liu Di graduated in2013 transform technology into productivity after the graduation work, he independently founded Beijing industry technology development co., LTD., it become the supplier 
of Chinese formula; three doctoral students graduated in 2016 abandon preferential treatment, they founded the Beijing Po wing new energy automotive technology co., LTD., cooperate with JieLanDe energy science and technology and Beijing new energy companies, the personal research were turned into products, hybrid electric vehicle controller for vehicle was developed to the market. Table 1 is nearly three years of undergraduate employment statistics, table 2 is nearly three years graduate employment statistics.

Table 1: Statistics on employment of undergraduates in recent three years

\begin{tabular}{|l|l|l|l|l|l|l|l|l|l|}
\hline Year & $\begin{array}{l}\text { Number of } \\
\text { people }\end{array}$ & $\begin{array}{l}\text { Directional } \\
\text { employment }\end{array}$ & $\begin{array}{l}\text { Available } \\
\text { employment }\end{array}$ & $\begin{array}{l}\text { Graduate } \\
\text { School }\end{array}$ & Abroad & Signing & Signing rate & Flexible & Unemployed \\
employment rate
\end{tabular}

Table 2: Statistics on employment of graduate in recent three years

\begin{tabular}{|l|l|l|l|l|l|l|l|l|l|}
\hline Year & $\begin{array}{l}\text { Number } \\
\text { of } \\
\text { people }\end{array}$ & $\begin{array}{l}\text { Directional } \\
\text { employment }\end{array}$ & $\begin{array}{l}\text { Available } \\
\text { employment }\end{array}$ & PhD & Abroad & Signing & $\begin{array}{l}\text { Signing } \\
\text { rate }\end{array}$ & Flexible & Unemployed \\
employment \\
rate
\end{tabular}

\section{References}

[1]. Liu Lili. Tutorial system of moral education research in China were reviewed [J]. Education science ,2014,(07):70-72. (In Chinese)

[2]. Zheng Weirong. The postgraduate exploration of moral education [J]. The graduate education,2015,(02):45-51. (In Chinese)

[3]. Luo Guang. Graduate student tutor's role in moral education research [D]. CCNU, 2008. (In Chinese)

[4]. Zhou Junfang. Analysis of moral education in colleges and universities: tutorial system of moral education [J]. Education and vocational, 2007,(17):83-84. (In Chinese)

[5]. Wang Lishu. Under the new situation, should strengthen the tutor of graduate students moral education work [J]. Journal of shandong youth management cadre institute, 2007,(03):70-72. (In Chinese)

[6]. Xie Jiahui, Cai Dongli. The tutor responsibility system under the graduate student moral education research [J]. Journal of Inner Mongolia normal university, 2006,(01):95-98. (In Chinese)

[7]. Chen Zihong, Shen Manhong. The graduate tutor system of exploration and practice of moral education [J]. Degree and postgraduate education, 2003,(06):22-25. (In Chinese)

[8]. Wang Taipeng,Yan Yan,Fan Wenhui. The integration of university undergraduate course education reform research and practice[A]. CETCU2013[C],2013:219-222.

[9]. Dai Xiuyun. Analyses college students' quality education structure and quality[J]. Journal of higher correspondence,2011,24(11):49-51. (In Chinese) 
[10]. Liu Ying, Yan Yan. Research on Personnel's Metewand Model Based on Brain Information Characteristics. IEEE International Conference on Management and Service Science. 2010,8.

[11]. Wang Ruihua. Explore the new mode of moral education resources optimal allocation and the integration [J]. Cultural and educational information, 2009, (30):176-178. (In Chinese)

[12]. Chu Yongzhi, Zhou Lizhi. Try to talk about the postgraduate moral responsibility and working mechanism building [J]. School party construction and ideological education, 2011, (32):7-10. (In Chinese)

[13]. Li Zuchao, Wang Xialu. Dominant mentor graduate students moral education model to explore [J]. Journal of national institute of education administration,2009,(04):65-68 (In Chinese) 